\title{
FILM DAN NOVEL DEAR NATHAN KARYA ERIK FEBRIAN DALAM PERSPEKTIF SASTRA BANDINGAN
}

\author{
Irpa Anggriani Wiharja ${ }^{1}$, Hendri Hendriyan Al Gardi ${ }^{2}$ \\ Universitas MuhammdiyahTangerang \\ Universitas Mathla'ul Anwar \\ irpawiharja@gmail.com ${ }^{1}$ \\ henrialgadri@gmail.com²
}

\begin{abstract}
ABSTRAK
Film dan Novel Dear Nahtan Karya Erik Febriani dalam Perspektif Sastra Bandingan. Tidak semua isi novel dapat terungkap dalam film yang ditayangkan, sehingga terkadang dapat menimbulkan kekecewaan pada penonton yang merasa tidak sesuainya isi novel dengan film yang ditayangkan. Penelitian ini bertujuan untuk mendeskripsikan skenario film Dear Nathan dengan novel Dear Nathan karya Erisca febriani, berupa plot, penokohan dan latar yang akan dianalisis melalui perspektif sastra bandingan. Penelitian ini menggunakan metode sastra bandingan. Teknik pengadaan data yang digunakan adalah teknik baca, menyimak dan mencatat dari hasil penelitian sumber data utama skenario, film dan novel Dear Nathan. Sedangkan data dianalisis dengan teknik deskriptif kualitatif. Untuk hasil penelitian diperoleh bahwa perbandingan plot antara skenario film Dear Nathan dengan novel Dear Nathan, keduanya menggunakan alur yang sama yaitu pembukaan, klimaks dan penyelesaian. Juga keduanya menggunakan alur sorot balik pada saat klimaks. Sedangkan perbandingan penokohan antara skenario film Dear Nathan dengan novel Dear Nathan memiliki perbedaan dan persamaan. Persamaannya adalah keduanya menguraikan penokohan pada setiap tokoh dengan karakter yang sama antara film dengan novel. Namun, perbedaannya adalah tokoh yang muncul dalam film dan novel berbeda, ada tokoh yang ditambahkan ataupun dihilangkan. Sedangkan untuk latar yang disampaikan dalam skeanrio film Dear Nathan dengan novel Dear Nathan, keduanya menggunakan latar tempat dan waktu. Mengenai latar tempat pada skenario film Dear Nathan, terdapat beberapa tempat yang tidak ada dalam novel Dear Nathan.
\end{abstract}

Kata kunci: Film, novel, perbandingan unsur pembangun.

\section{A. PENDAhuluan}

Fungsi sastra sebagai sarana hiburan dan pendidikan dapat diperoleh melaluli sebuah karya sastra seperti novel, cerpen, puisi, drama atau film. Saat ini, salah satu karangan yang banyak diminati adalah film. Film banyak diminati karena tidak hanya dibaca dan didengar, tetapi juga dapat dilihat sehingga mudah untuk dipahami. Oleh karena itu, film mudah mempengaruhi pola pikir seseorang dengan cerita yang disampaikan,sehingga pemilihan film yang baik sangat diperlukan. Film yang baik merupakan film yang dapat menginspirasi penonton, dapat dilihat dari bentuk cerita yang disampaikan kepada penonton. Biasanya penonton akan banyak terpengaruh hal yang ditampilkan, seperti adegan, gaya busana,dan bahasa. Sama halnya dengan film, saat ini novel juga banyak digemari berbagai kalangan. 
Meskipun novel tidak dapat didengar, tetapi novel tetap menjadi daya yang menarik. Novel juga dapat dijadikan sebagai media hiburan dan pengetahuan. Melalui novel terdapat hal positif yang dapat diperoleh seperti amanat yang disampaikan oleh pengarang secara tersirat maupun tersurat.

Pengetahuan lain yang dapat kita peroleh melalui novel yaitu pengetahuan dalam menambah pembendaharaan kata melalui bahasa yang digunakan, budaya yang disampaikan dan pendidikan. Dampak dari banyaknya kalangan yang menyukai antara novel dan film, maka kini pengangkatan novel menjadi sebuah film telah menjadi trend yang menarik perhatian. Salah satu novel yang difilmkan adalah novel Dear Nathan yaitu sebuah karya sastra cerita fiksi karangan Erisca Febriani. Erisca Febriani dapat dikatakan sebagai pencetus penulis remaja yang saat ini dapat menginspirasi remaja lainnya untuk menulis.

Cerita yang disampaikan dalam Dear Nathan merupakan kisah remaja dengan aktor utama bernama Nathan. Cerita Dear Nathan bukan hanya membahas kisah cinta saja seperti cerita romantis pada umumnya. Tetapi di dalamnya juga membahas konflik persahabatan dan keluarga dengan amanat yang disampaikan penulis secara tersirat dan tersurat. Penyampaian cerita Dear Nathan disampaikan sangat ringan sehingga mudah dimengerti oleh pembaca atau penikmat film. Pada film Dear Nathan, tidak semua isi novel Dear Nathan dapat dituangkan ke dalam film Dear Nathan. Hal tersebut karena film Dear Nathan hanya berdurasi 01:44 menit. Sedangkan novel Dear Nathan untuk ceritanya berjumlah 497 halaman ditambah dengan lampiran lain menjadi 512 halaman, karena itu tentu banyak perbedaan dan perubahan yang ada antara novel dengan film yang ditayangkan.

Selain itu, perbedaan antara novel dan film juga disebabkan perubahan dari bentuk novel menjadi film adalah hal yang sulit, karena perlu adanya perubahan dari deskripsi penyampaian cerita menjadi cerita dengan gambar yang bergerak dan perlu adanya proses adaptasi antara novel untuk menjadi sebuah film. Perbedaan dan pembaharuan seperti hal yang ditambahkan atau dihilangkan, termasuk perbedaan unsur pembangun yang ada di dalam novel Dear Nathan berbeda dengan unsur pembangun pada sebuah film. Tidak semua isi novel dapat terungkap dalam film yang ditayangkan. Sehingga terkadang dapat menimbulkan kekecewaan pada penonton yang merasa tidak sesuainya isi novel dengan film yang ditayangkan. Oleh karena itu, dengan menganalisis karyanya diharapkan peneliti dapat membandingkan dan menganalisis unsur pembangun novel Dear Nathan dengan unsur pembangun film Dear Nathan karya Erisca Febriani. 


\section{B. KAJIAN TEORI}

Sebuah sastra diciptakan atas dasar tujuan dan fungsi dalam penciptaannya sebagai sarana hiburan dan pendidikan, seperti yang diungkapkan oleh Teeuw (2013:20), "Kata sastra dalam bahasa Indonesia berasal bahasa Sansekerta; akar kata $h s^{-}$, dalam kata kerja turunan berarti mengarahkan, mengajar, memberi petunjuk atau intruksi. Akhiran -tra biasanya menunjuk alat, sarana”. Untuk itu, salah satu fungsi sastra sebagai sarana pendidikan dapat digunakan sebagai media untuk mengarahkan dan memberi pengajaran. Endraswara (2011:1) berpendapat mengenai sastra bandingan, ia mengatakan "Kata bandingan berasal dari kata "banding" dalam konteks ini ada pula menyebut sastra perbandingan. Bandingan berarti tara/timbangan atau imbangan. Bandingan dapat diartikan pula membanding (to compare) dari berbagai aspek".

Setiap disiplin ilmu tentu memiliki perkembangan teori, termasuk sastra bandingan yang telah dikenal luas di dunia akademik yang mempunyai proses perkembangan tersendiri.Seperti yang diungkapkan oleh Damono (2015:13) mengenai perkembangan sastra bandingan di Eropa, "Bahasa-bahasa di Eropa yang beberapa diantaranya mirip satu sama lain itu menghasilkan kesusastraan yang berbeda-beda, yang dengan bebas bergerak dari satu kebudayaan ke kebudayaan lain".

Penelitian sastra bandingan tentu memiliki bidang atau objek kajian dalam melakukan penelitian. Seperti yang diungkapkan oleh Wellek dan Waren (2014:44) "Istilah sastra bandingan dalam praktiknya menyangkut bidang studi masalah lain”. Menurutnya yang dimaksud studi masalah lain yaitu, pertama istilah perbandingan ini dipakai untuk studi sastra lisan, terutama cerita-cerita rakyat dan migrasinya, serta bagaimana dan kapan cerita rakyat masuk ke dalam penulisan sastra yang lebih artistik. Kedua istilah sastra bandingan mencakup studi hubungan antara dua kesusastraan atau lebih. Pendekatan ini dipelopori oleh kelompok ilmuan Prancis yang disebut comparatistes, dipimpin oleh Fernand Baldensperger. Ketiga istilah sastra bandingan disamakan dengan studi sastra menyeluruh. Jadi, sama dengan sastra dunia, sastra umum atau sastra universal. Kajian sastra bandingan dapat dikaji beberapa praktik penelitian yaitu dalam meneliti asal usul masuknya cerita rakyat, meneliti hubungan antara dua kesusastraan atau lebih, dan sastra bandingan mengkaji perbandingan studi sastra menyeluruh atau sama dengan sastra umum, universal dan sastra dunia.

Novel merupakan sebuah karya sastra yang di dalamnya berisi jalan cerita mengenai kehidupan nyata.Hal ini seperti yang diungkapkan Azies dan Hasim (2013:7) "Novel merupakan sebuah genre sastra yang memiliki bentuk utama prosa dengan panjang yang 
kurang lebih bisa untuk mengisi satu atau dua volume kecil, yang menggambarkan kehidupan nyata dalam suatu plot yang cukup kompleks". Sebuah novel memiliki bentuk prosa yang berbeda dari prosa lainnya, novel juga merupakan sebuah cerita fiksi, cerita fiksi tersebut biasanya menceritakan kehidupan nyata.

Film merupakan gambar yang bergerak dan memiliki suara, banyak film yang diangkat dari kisah nyata, novel atau pun cerita fiksi karangan pengarang. Film menurut Damono (2012:91) "Film adalah jenis kesenian yang paling muda, sebelum adanya televisi. Televisi itu sendiri pada dasarnya adalah film, yakni gambar bergerak yang kita tonton di layar.Film merupakan sebuah gambar tayangan yang ada dalam televisi, gambar tersebut berupa gambar yang bergerak. Unsur pembangun film merupakan pendukung terciptanya sebuah film. Fachrudin (2015) mempunyai teori tersendiri, menurutnya film termasuk ke dalam jenis drama televisi yang berbentuk skenario cerita yang kemudian ditampilkan dalam film, sinetron atau novela. Ia mengungkapkan unsur-unsur cerita drama/film yaitu, judul, kerabat kerja, ide cerita, inti cerita, tema, pesan moral, sudut pandang, gaya bahasa, intrik, segitiga membangun konflik, klimaks, pola cerita, ketegangan, keingintahuan, kejutan, milieu, pikatan, dan penggoda.

\section{METODE PENELITIAN}

Penelitian ini termasuk penelitian kualitatif dengan kajian sastra bandingan. Penelitian sastra bandingan merupakan penelitian dengan pendekatan yang bersifat komparatif atau membandingan persamaan dan perbedaan sifat dan fakta objek penelitian dengan secara kritis atau pengembangan kesadaran tindakan kritis penelitian dalam menghadapi masalah-masalah sosial. Metode yang digunakan dalam penelitian ini adalah metode analisis isi yang merupakan metode yang berorientasi pada penelitian isi suatu objek penelitian. Sumber data penelitian adalah skenario film Dear Nathan penulis Bagus Bramanti serta film Dear Nathan sutradara Indra Gunawan dengan novel Dear Nathan karya Erisca Febriani. Untuk skenario film diperoleh dari sutradara Indra Gunawan, sedangkan film dan novel Dear Nathan diperoleh dari Gramedia. Teknik pengadaan data yang digunakan adalah teknik baca, menyimak dan mencatat dari hasil penelitian sumber data utama skenario, film dan novel Dear Nathan. Sedangkan data dianalisis dengan teknik deskriptif kualitatif. 


\section{HASIL PENELITIAN DAN PEMBAHASAN}

Pembahasan difokuskan pada Perbandingan unsur pembangun film Dear Nathan dengan unsur pembangun novel Dear Nathan karya Erisca Febriani, berupa : Plot, penokohan, dan latar.

\section{a. Plot}

Struktur cerita, munculnya cerita satu akan mempengaruhi cerita selanjutnya atau suatu urutan cerita atau peristiwa yang teratur dan terorganisasi. Film Dear Nathan menampilkan dua tokoh sebagai fokus utama yaitu Salma dan Nathan. Alur kehidupan Salma dan Nathan pertama kali dimulai saat mereka bertemu di depan gerbang SMA Garuda pada pagi hari, pertemuan tersebut dikarenakan Salma terlambat masuk sekolah. Seperti dalam kutipan skenario film berikut.

Nathan : "Telat upacara aja kayak telat dateng bulan. Tegang amat."

Emosi Salma langsung melonjak. Dia manatap ke belakang. Ada Nathan (16), seorang siswa ganteng namun acak-acakan tengah berdiri. Baju dikeluarkan. Dasi tak pakai. Ia tampak super tenang, berbeda dengan Salma yang was-was.

Setelah pertemuan pertama itu, alur selanjutnya terdapat beberapa konflik yang terjadi pada tokoh utama Nathan, seperti Ibunya Nathan yang memanggil ia dengan nama Daniel, Ayah Nathan yang menikah lagi, serta sikap Nathan yang arogan dan sering berkelahi. Penyebab masalah tersebut belum disampaikan sutradara pada awal cerita. Hingga pada puncaknya rahasia tersebut terbongkar. Penyebabnya berhubungan dengan kisah Nathan pada masa lalu ketika adik Nathan yang bernama Daniel meninggal dan Nathan disalahkan atas kematiannya. Seperti dalam kutipan skenario film berikut.

"Dua tahun lalu gua janjian sama preman kampung di gudang ini, Daniel yang gak tau apa-apa dia diseret ke tempat ini pas pulang sekolah, mereka kira Daniel itu saya, dia di hajar habis-habisan sampe nyawanya ga bisa ketolong lagi. Mamah ga bisa nerima kejadian itu, setiap kali gua ketemu mamah, nama Daniel yang selalu dia sebut, papa nikah lagi semenjak mama punya masalah.”

Kutipan di atas menunjukan plot utama dalam cerita Dear Nathan karena menghubungkan sebab akibat yang menjadikan karakter dan tokoh Nathan serta penyebab jalannya cerita. Pengarang menyampaikan plot tersebut berdasarkan kriteria plot sorot balik. Plot sorot balik dilakukan dengan cara tokoh Nathan merenung kembali ke masa lalu dan menceritakannya kepada tokoh Salma secara lisan, sehingga pembaca dapat mengetahui kejadian di masa lalu yang terjadi pada tokoh Nathan hingga menyebabkan saling beruhubungan antar cerita. Pada penutupan cerita dalam skenario film Dear Nathan yaitu 
Salma memberikan surat kepada Nathan dengan judul surat Dear Nathan. Seperti dalam kutipan berikut.

Sebuah amplop dipegang di tangan Nathan. terlihat segel plester laminating pemberian Nathan dibuka. Nathan membaca dengan serius.

Maka dapat disimpulkan bahwa plot dalam skenario film Dear Nathan dengan tiga tahapan yaitu awal cerita, tengah dan akhir cerita. Dengan struktur plot inciting forces, klimaks dan peleraian. Sedangkan plot pada film Dear Nathan termasuk plot sorot balik, flash back karena menceritakan cerita yang tidak dimulai dari tahap awal, melainkan dari tahap tengah dan kembali ke awal cerita kemudian penyelesaian dan tahap akhir.

Sedangkan pada novel, alur cerita Dear Nathan bermula saat Nathan dan Salma bertemu pertama kali, mereka bertemu di depan gerbang Sekolah saat Salma dan Nathan terlambat masuk sekolah. Saat itu, keduanya masuk melalui pintu rahasia. Seperti dalam kutipan berikut.

“Telat?" Tanya cowok itu sambil menyentil batang rokok yang sudah habis terisap masuk ke got dekat gerbang. "I-iya." Salma mengangguk takut.

Dari kutipan di atas menggambarkan pertemuan Salma dan Nathan, sekaligus memperkenalkan tokoh utama dan latar utama pada cerita novel Dear Nathan. Pada awal pembukaan cerita, selain pengarang memperkenalkan adanya tokoh Salma dan Nathan, juga memperkenalkan adanya tokoh tambahan yang nantinya akan mengikuti alur cerita dari awal hingga akhir yaitu Orlin, Rahma dan Meysha. Seperti pada kutipan berikut.

"Semuanya berawal dari hari pertamanya masuk sekolah dan di sambut dengan gosip dari Afifah, anak kelas 10-6 yang akrab dengan Orlin, Meyha dan Rahma yang tiap istrihat selalu lari ke kelas 10-2 untuk berbagi cerita."

Alur cerita novel Dear Nathan pada awal cerita banyak memperkenalkan tempat dan tokoh yang akan barperan nantinya. Meskipun tetap fokus utama pada tokoh Nathan dan Salma. Maka dapat disimpulkan bahwa plot dalam novel Dear Nathan dengan tiga tahapan yaitu awal cerita, tengah dan akhir cerita. Dengan struktur plot inciting forces, klimaks dan peleraian. Sedangkan plot pada novel Dear Nathan juga termasuk plot sorot balik, flash back karena menceritakan cerita yang tidak dimulai dari tahap awal, melainkan dari tahap tengah dan kembali ke awal cerita kemudian penyelesaian dan tahap akhir.

Perbandingan secara keseluruhan plot pada film dan novel Dear Nathan mempunyai alur yang sama, dalam hal pembukaan, klimaks dan cara penyelesaian yaitu melalui tokoh Salma. Alur yang disampaikan juga sama yaitu alur sorot balik karena pada saat klimaks cerita, yang kembali menceritakan penyebab utama yang berkaitan dengan cerita sebelumnya. 
Lingua Rima: Jurnal Pendidikan Bahasa dan Sastra Indonesia

Vol. 9 No. 2 Juli 2020

\section{b. Penokohan}

Perbandingan penokohan dalam film dan novel Dear Nathan yaitu, pada film berjumlah 33 tokoh. Sedangkan pada novel berjumlah 49 tokoh dengan penokohan masingmasing. Secara keseluruhan meskipun tokoh antara film dan novel Dear Nathan berbeda. Tetapi keduanya menggunakan tokoh dan penokohan utama yang sama serta peran tokoh lainnya hampir serupa. Beberapa tokoh yang diceritakan pada film dan novel Dear Nathan yaitu.

1) Nathan Januar Prasetio

Pada skenario film disampaikan tokoh Nathan yaitu sebagai siswa SMA usia 16 tahun, berwatak nakal karena sering melanggar aturan sekolah, seperti yang disampaikan pada kutipan berikut.

Ada Nathan (16), seorang siswa yang ganteng namun acak-acakan tengah berdiri. Baju dikeluarkan. Dasi tak di pakai.

Kutipan skenario di atas, disampaikan pengarang menggunakan teknik ekspositori yaitu menguraikan tokoh Nathan dengan cara memberikan penguraian dan penjelasan secara langsung. Nathan juga berperan sebagai tokoh utama dalam film Dear Nathan. Hal tersebut dikarenakan konflik sesungguhnya terjadi pada diri Nathan, dan Nathan berkaitan dengan seluruh isi cerita.

2) Salma Alvira

Salma merupakan tokoh tambahan yang utama, ia adalah tokoh yang serba tahu dalam cerita dan selalu terlibat dengan tokoh utama Nathan. Dalam film Salma merupakan seorang siswa perempuan yang berusia 16 tahun, seperti dalam kutipan skenario film berikut.

Salma (16) seorang siswa berseragam putih abu-abu.

Selanjutnya penokohan Salma yaitu suka menolong, seperti dalam kutipan berikut.

Salma melihat seseorang. Salma, laki-laki (40an) memakai kaca mata hitam dan peci, seorang tuna netra. Dia tampak ingin melintas ke sisi jalan di sebrang. Salma, meskipun dengan wajah enggan, akhirnnya menuntun laki-laki itu untuk menyebrang.

Pelukisan dalam skenario film tersebut menggambarkan Salma mempunyai watak suka menolong, karena terdapat adegan saat Salma membantu menyebrang seorang tuna netra. Selain itu, teknik pelukisan tokoh Salma juga disampaikan dengan teknik dialog berikut.

"Iya deh iya. Gue bilang lo, tuh, pendiem. Kutu buku. Cuek bebek." 
Dialog Rahma di atas, secara langgsung mengungkapkan tokoh Salma yang pendiam dan suka membaca buku. Sedangkan dalam novel Salma juga digambarkan sebagai tokoh yang pendiam dan suka membaca buku. Seperti dalam kutipan berikut

"Gue jawab, Salma itu anaknya pendiam, cuek, kutu buku, kadang nyebelin, terus doyan baca novel, kadang suka buat cerita juga.

Dialog Rahma tersebut secara langsung menilai tokoh Salma, sehingga pembaca dapat menyimpulkan penokohan Salma. Pengarang juga menyampaikan ciri fisik Salma yang bertubuh mungil. Hal ini secara langsung disampaikan oleh pengarang melalui kutian berikut. Tiba-tiba Nathan melakukan rem mendadak hingga tubuh mungil Salma terdorong ke depan.

Perbandingan penokohan Salma dalam skenario film dan novel Dear Nathan mempunyai persamaan yaitu Salma sebagai seorang siswi yang berusia 16 tahun, pendiam dan mempunyai hobi membaca buku

\section{c. Latar}

Sebagai bentuk pendukung jalannya cerita berupa tempat, waktu dan latar sosial budaya.

\section{1) Gerbang Depan Sekolah}

Salah satu latar yang ada dalam skenario film Dear Nathan yaitu digerbang depan sekolah. Hal ini terjadi pada saat Nathan dan Salma yang masuk ke lingkungan sekolah menggunakan motor. Seperti kutipan pada skenario film berikut.

SMA Garuda - Gerbang - Pagi

Motor Nathan masuk ke dalam parkiran sekolah. Para siswa yang lalu lalang di gerbang, memandangi Salma yang dibonceng Nathan dengan raut aneh sekaligus penasaran. Beberapa di antara mereka bisik-bisik sambil tersenyum, geli di belakang. Salma memperhatikan hal tersebut dengan risih.

Secara jelas latar tempat dalam film di atas yaitu di Gerbang Depan SMA Garuda, dan latar waktu yaitu pagi hari karena menunjukan kapan peristiwa tersebut terjadi, dengan suasana banyaknya siswa yang memperhatikan Salma dan Nathan dengan saling pandang. Sedangkan dalam novel diceritakan saat Salma menunggu angkutan umum di depan gerbang sekolah. Seperti dalam kutipan berikut.

"Biasanya Salma memang naik angkutan umum, berhubung ini sudah sangat sore maka Salma memilih untuk lebih dijemput. Cewek itu berdakiri di depan gerbang sekolah sudah sepi.

Latar yang diungkapkan melalui kutipan novel di atas yaitu di depan gerbang sekolah. Kutipan di atas juga menunjukan adanya latar waktu pada sore hari. Suasana juga disampaikan pengarang yaitu suasana yang sepi sehingga pembaca seolah-olah dapat ikut merasakan suasana tersebut. 
Perbandingan antara film dan novel dalam cerita Dear Nathan sama-sama menggunakan latar tempat yaitu gerbang SMA Garuda, Gerbang SMA Garuda yaitu salah satu lokasi terjadinya cerita. Dan pada film dan novel mempunyai suasana tertentu dalam menyampaikan cerita yang berlatar gerbang sekolah.

\section{2) Gerbang Kantin Sekolah}

Pada skenario film Dear Nathan terdapat adegan pada saat Salma dan Nathan terlambat masuk sekolah dan mereka harus melewati gerbang samping dengan cara menaiki tangga.

Salma menginjak pundak Nathan untuk naik ke atas gerbang. Kakinya Nampak gemetar.

Selain mengungkapkan latar tempat, sutradara juga mengungkapkan latar waktu yaitu pada pagi, dengan suasana kekhawatiran Salma yang terlambat masuk sekolah. Sedangkan pada novel juga diceritakan adanya latar tempat gerbang kantin sekolah yaitu pada saat Salma terlambat masuk sekolah. Seperti kutipan beirikut.

"Bentar lagi gurunya bakal datang," katanya sewaktu Salma sudah berjalan mendekati gerbang samping yang ternyata baru saja dibuka oleh penjaga kantin belakang.

Kutipan novel di atas, pengarang mengungkapkan secara langsung lokasi dalam cerita yaitu di gerbang samping sekolah. Tanpa memberitahukan latar waktu pada peristiwa tersebut. Tetapi dari cerita yang disampaikan Salma masuk melalui gerbang samping sekolah merupakan pagi hari karena Salma baru saja datang ke sekolah.

Latar antara film dan novel keduanya menggunakan latar tempat gebang samping sekolah, dalam kutipan film dan novel di atas, keduanya sama-sama menceritakan Salma yang akan masuk ke sekolah melalui gerbang samping, tapi ada perbedaan suasana yang diceritakan, yaitu pada film suasana tersebut terdapat warung yang ada di pinggir jalan dan Salma harus memanjat untuk bisa masuk. Tetapi dalam novel Salma masuk gerbang samping karena dibukakan oleh penjaga kantin.

Secara keseluruhan perbandingan latar antara novel dan film Dear Nathan yaitu, pada film berjumlah latar adalah 40 latar. Sedangkan pada novel berjumlah 49 latar. Meskipun mempunyai jumlah yang berbeda tetapi keduanya sama-sama menggunakan latar utama sekolah sebagai pendukung jalannya cerita Dear Nathan.

\section{E. SIMPULAN DAN SARAN}

Berdasarkan kajian flm dan novel Dear Nathan karya Erisca Febriani menjelaskan Film dan novel mempunyai unsur pembangun yang berbeda untuk menampilkan sebuah hasil 
karya sastra. Maka perbandingan antara film dan novel Dear Nathan dilihat dari sudut unsur pembangun memiliki beberapa perbedaan dan persamaan. Pertama untuk plot pada film dan novel Dear Nathan terdiri dari 3 plot yang ditampilkan, dengan alur cerita yang sama. Berupa pembukaan diawali dengan perkenalaln tokoh dan tempat, kemudian konflik mulai dimunculkan sampai akhirnya menuju klimaks, dan proses penyelesaian sampai akhir cerita tidak ada perbedaan antara film dan novel Dear Nathan. Kedua untuk penokohan pada film dan novel Dear Nathan mempunyai perbedaan yaitu penokohan pada film Dear Nathan berjumlah 36 tokoh. Sedangkan pada novel Dear Nathan berjumlah 49 tokoh. Kemudian latar pada film Dear Nathan berjumlah 40. Sedangkan pada novel Dear Nathan berjumlah 49 temuan. Dari data tersebut terlihat bahwa jumlah temuan pada novel lebih banyak dibandingkan film Dear Nathan. Hal ini dikarenakan film yang diangkat dari sebuah novel, tidak semua dapat disalurkan kepada tayangan film, karena unsur pembangunnya yang berbeda. Selain itu, untuk novel berupa tulisan yang bisa dibaca kapan pun. Sedangkan pada film terbatas pada durasi waktu film yang ditayangkan. Terutama film Dear Nathan ditayangkan melalui bioskop yang mempunyai batas waktu. Meskipun tidak semua latar dan tokoh novel Dear Nathan dapat dituangkan melalui film Dear Nathan, tetapi alur cerita yang ditampilkan serta penafsiran penonton masih sama dengan menafsirkan isi novel Dear Nathan karena plot yang ditampilkan sesuai antara novel dan film Dear Nathan.

\section{F. DAFTAR PUSTAKA}

Aziez, F \& Hasim, A (2010). Menganalisis Fiksi. Bogor: Ghalia Indonesia.

Damono, S, D. (2012). Sastra Bandingan. Ciputat: Editum. (2015). Sastra Bandingan. Ciputat: Editium.

Endraswara,S. (2011). Metodelogi Penelitian Sastra Bandingan. Jakarta:Bukupop. Fachrudin, A. (2013). Manajemen Produksi Program Acara TV. Jakarta: PT Grasindo. Teeuw, A. (2013). Sastra dan Ilmu Sastra. Bandung: Pustaka Jaya. Wellek, R \& Waren, A (2014). Teori Kesusastraan. Jakarta: PT Gramedia Pustaka Utama. 